International Journal of Current Micro6iology and Applied Sciences

ISSN: 2319-7706 Volume 9 Number 1 (2020)

Journal homepage: http://www.ijcmas.com

\title{
Roll of Organic Manures and Different Doses of N, P, K on Growth, Establishment and Percentage of Survival of Sweet Orange (Citrus sinensis Osbeck) Grafted Plants
}

\author{
Jayram Verma, Sevan Das Khunte*, Sandeep Lakra and V. M. Prasad
}

Department of Horticulture, Allahabad School of Agriculture, Sam Higginbottom Institute of Agriculture, Technology and Sciences

(Deemed to-be University), Allahabad-211007 (U.P.) India

*Corresponding author

A B S T R A C T

\section{Keywords}

organic manure (FYM), N, P,K and Sweet orange.

Article Info

Accepted:

15 December 2019 Available Online:

20 January 2020
A field experiment was conducted the Crop Research Farm, Department of Horticulture, Allahabad School of Agriculture, SHIATS, Allahabad (U.P.) The present investigation entitled Roll of organic manures and different doses of N,P,K on growth, establishment and percentage of survival of Sweet orange (Citrus sinensis Osbeck) grafted plants. The experiment was laid out in randomized block design with 03 replications and 13 treatments separately. The material used in the experiment was organic manures and inorganic fertilizers (NPK). Studies showed that significant effect on maximum plant height $(62.55 \mathrm{~cm})$, number of Branches $(9.22)$, number of Leaves(49.10), petiole length $(1.90 \mathrm{~cm})$, Plant Girth $(8.53 \mathrm{~cm})$, Plant Survival percentage $(100 \%)$, and minimum Dead plant percentage $(0.0 \%)$ was recorded in treatment with $\mathrm{T}_{12} 8 \mathrm{~kg} /$ plant Farm Yard Manure $+120 \mathrm{~g}$ / plant Nitrogen, $45 \mathrm{~g} /$ plant Phosphorus and $30 \mathrm{~g} / \mathrm{plant}$ Potash under Allahabad agro-climatic conditions.

\section{Introduction}

The Sweet orange (Citrus sinensis Osbeck) is the members of family Rutaceae sub-family Aurantoideae (Tanaka, 1977) and a single genus contains the most important species, sweet orange, mandarin, lemon, lime, citrus, grape fruit and the shaddock. All these are excellent source of vitamin ' $\mathrm{C}$ ' \& fruit acids and are appreciated all over the world for their "fruity" fruit taste and refreshing qualities. The cultivated species of citrus are believed to be the native of Southeast Asia. It is a Climacteric fruits and mainly grown in United States, Brazil, Mexico, India \& Argentina. The cultivated species of Sweet orange are 
believed to be the native of South East Asia or Indo-China and Commercially grown dry semi-arid to subtropical regions in India (Muthukumar and Selvakumar, 2013). It is susceptible to water logging so water stagnation in orchard should be avoided (Gupta, 2012). In the world India is the third largest citrus The major citrus fruits in India are mandarin orange, sweet orange and acid lime group of fruit crops production of 2.98 million tonnes from 0.37 million ha. In India mostly growing Punjab, Rajasthan, Maharashtra, MP. Bihar, KR, Gujarat and AP.(Nilangekar and Patil 1982).Different states recommend different amounts of NPK for mandarin and other important citrus species in India. It varies from 300-400 $\mathrm{g}$ of $\mathrm{N}, 200$ to $375 \mathrm{~g}$ of P2O5and 100 to $600 \mathrm{~g}$ of $\mathrm{K} 2 \mathrm{O}$ per plant per year. Recently, integrated nutrient management (INM) is being advocated in citrus., the proper manuring and fertilizer application has to be resorted for obtaining highest yields and quality fruit production which depends upon healthy and sturdy tree growth).

\section{Role of organic manures in Sweet orange}

\section{Farm Yard Manure (FYM)}

The decomposed mixture of dung and urine of farm animal salong with litter and left over materials from roughages or fodder fed to the cattle. On an average well decomposed farmyard manure contains $0.5 \% \mathrm{~N}, 0.2 \% \mathrm{P}_{2} \mathrm{O}_{5}$ and $0.5 \%$ K2O.Farmyard manure (FYM) is one of the more valuable organic fertilizers maintaining soil fertility in the systems of alternative agriculture it is important to improve soil fertility and at the same time to protect and improve soil physical condition for its healthy functioning. Maintenance and improvement of soil potential fertility are closely related to the maintenance of soil organic matter and organic carbon balance (Baksiene et al., 2014). Soil organic matter
(SOM) plays a crucialrole in maintaining sustainability of cropping systems by improving soil physical, chemical and biological properties (Diacono and Montemurro, 2010; Fageria, 2012). The study investigated the influence of FYM on the crop yields and metabolizable energy from the crop

Rotation, changes in the soil agrichemical properties; the cost-benefit (profitability) for the FYM utilization was calculated. The following hypothesis was tested: the application of FYM in organically managed crop rotation is environmentally friendly and economically profitable (Malle, J. 2017). The maximum number of branches (9.22) was recorded in 150 days with treatment $\mathrm{T}_{12}(8$ $\mathrm{kg} /$ plant FYM $+120 \mathrm{~g} /$ plant $\mathrm{N}+45 \mathrm{~g} /$ plant $\mathrm{P}$ $+45 \mathrm{~g} /$ plant $\mathrm{K}$ ) followed by (8.99) treatment $\mathrm{T}_{9}(8 \mathrm{~kg} /$ plant $\mathrm{FYM}+90 \mathrm{~g} /$ plant Nitrogen + $45 \mathrm{~g} /$ plant $\mathrm{P}+45 \mathrm{~g} /$ plant $\mathrm{K}$ )while the minimum number of branches (7.11) was recorded in treatment $\mathrm{T}_{0}$ (control).

\section{Role of inorganic fertilizers in sweet orange}

\section{Nitrogen}

Nitrogen is an essential component of all proteins. Nitrogen deficiency most often results in stunted growth. Nitrogen $(\mathrm{N})$ is a key nutrient for production of citrus fruits, and the element plays an important role in vegetative and reproductive growth (Alva and Paramasivam 1998). The maximum plant height $(62.55 \mathrm{~cm})$ was recorded in 150 days with treatment $\mathrm{T}_{12}(8 \mathrm{~kg} /$ plant $\mathrm{FYM}+120$ $\mathrm{g} /$ plant $\mathrm{N}+45 \mathrm{~g} /$ plant $\mathrm{P}+45 \mathrm{~g} /$ plant K)followed by $(61.44 \mathrm{~cm})$ treatment $\mathrm{T}_{9}(8$ $\mathrm{kg} /$ plant FYM + 90g/plant $\mathrm{N}+45 \mathrm{~g} /$ plant $\mathrm{P}+$ $45 \mathrm{~g} /$ plant $\mathrm{K}$ ) while the minimum plant height $(28.88 \mathrm{~cm})$ was recorded in treatment $\mathrm{T}_{0}$ (control).The maximum dead plants percentage $(25 \%)$ was recorded in treatment $\mathrm{T}_{0}$ (Control) while the minimum dead plants percentage $(00 \%)$ was recorded in treatment 
$\mathrm{T}_{12}(8 \mathrm{~kg} /$ plant $\mathrm{FYM}+120 \mathrm{~g} /$ plant $\mathrm{N}+45$ $\mathrm{g} /$ plant $\mathrm{P}+45 \mathrm{~g} /$ plant $\mathrm{K})$.

\section{Phosphorus}

Phosphorus is important in plant bioenergetics. As a component of ATP, Phosphorus is needed for the conversion of light energy to chemical energy (ATP) during photosynthesis. Improper and inadequate nutrition is one of the major causes of citrus decline in India. Studies on the decline of mandarins in Kerala showed that poor nutrient status of soil and neglect and lack of manuring are the main causal factors. Different states recommend different amounts of NPK for mandarin and other important citrus species in India. It varies from 300-400 $\mathrm{g}$ of $\mathrm{N}, 200$ to $375 \mathrm{~g}$ of $\mathrm{P}_{2} \mathrm{O}_{5}$ and 100 to $600 \mathrm{~g}$ of $\mathrm{K}_{2} \mathrm{O}$ per plant per year.

Recently, integrated nutrient management (INM) is being advocated in citrus, the proper manuring and fertilizer application has to be resorted for obtaining highest yields and quality fruit production which depends upon healthy and sturdy tree growth. Phosphorus is important in plant bioenergetics. As a component of ATP, Phosphorus is needed for the conversion of light energy to chemical energy (ATP) during photosynthesis and properly growth of plant. The maximum number of leaves (49.10) was recorded in 150 days with treatment $\mathrm{T}_{12}(8 \mathrm{~kg} / \mathrm{plant} \mathrm{FYM}+$ $120 \mathrm{~g} /$ plant $\mathrm{N}+45 \mathrm{~g} /$ plant $\mathrm{P}+45 \mathrm{~g} / \mathrm{plant} \mathrm{K}$ ) followed by (48.11) treatment T9 $(8 \mathrm{~kg} / \mathrm{plant}$ FYM+ 90g/plant $\mathrm{N}+45 \mathrm{~g} /$ plant $\mathrm{P}+45 \mathrm{~g} /$ plant $\mathrm{K})$ and the minimum number of leaves (39.22) was recorded in treatment $\mathrm{T}_{0}$ (control). The maximum petiole length $(1.90 \mathrm{~cm})$ was recorded in 150 days with treatment $\mathrm{T}_{12}(8$ $\mathrm{kg} /$ plant FYM $+120 \mathrm{~g} /$ plant $\mathrm{N}+45 \mathrm{~g} /$ plant $\mathrm{P}$ $+45 \mathrm{~g} / \mathrm{plant} \mathrm{K})$ followed by (1.88) treatment T8 $(8 \mathrm{~kg} / \mathrm{plant}$ FYM $+90 \mathrm{~g} / \mathrm{plant} \mathrm{N}+$ $30 \mathrm{~g} /$ plant $+\mathrm{P}+30 \mathrm{~g} /$ plant $\mathrm{K}$ ) while the minimum petiole length $(1.81 \mathrm{~cm})$ was recorded in treatment $\mathrm{T}_{0}$ (control).
Potash

Potassium regulates the opening and closing of the stoma by a potassium ion. Since stomata are important in water regulation, potassium reduces water loss from the leaves and increases drought tolerance. Potassium deficiency may cause necrosis or interveinal chlorosis, leaf scotch, Die-back of lateral bud. The maximum stem girth $(8.53 \mathrm{~cm})$ was recorded in 150 days in treatment $\mathrm{T}_{12}(8$ $\mathrm{kg} / \mathrm{plant}$ FYM $+120 \mathrm{~g} /$ plant $\mathrm{N}+45 \mathrm{~g} / \mathrm{plant} \mathrm{P}$ $+45 \mathrm{~g} /$ plant $\mathrm{K})$ followed by $(8.37 \mathrm{~cm})$ treatment $\mathrm{T}_{9}(8 \mathrm{~kg} /$ plant $\mathrm{FYM}+90 \mathrm{~g} /$ plant $\mathrm{N}$ $+45 \mathrm{~g} /$ plant $\mathrm{P}+45 \mathrm{~g} /$ plant $\mathrm{K}$ )and the minimum $(6.83 \mathrm{~cm})$ was recorded in treatment $\mathrm{T}_{0}$ (control).Potassium regulates the opening and closing of the stoma by a potassium ion pump. Since stomata are important in water regulation, potassium reduces water loss fromthe leaves and increases drought tolerance. The maximum plant survival percentage $(100 \%)$ was recorded in 150 days with treatment $\mathrm{T}_{12}(8$ kg/plant FYM + 120 g/plant N + 45 g/plant P+ $45 \mathrm{~g} /$ plant $\mathrm{K}$ ) while the minimum plant survival $(75 \%)$ was recorded in treatment with $\mathrm{T}_{0}$ (control).

The present investigation at the Experimental Field of the Department of Horticulture, Allahabad School of Agriculture, Sam Higginbottom Institute of Agriculture, Technology and Sciences (Deemed to-be University), Allahabad U.P. It was concluded that the maximum plant height, number of branches, number of leaves, petiole length, plant girth and the minimum dead plants percentage $(0.0 \%)$ was recorded in treatment $\mathrm{T}_{12}(8 \mathrm{~kg} / \mathrm{plant} \mathrm{FYM}+120 \mathrm{~g} /$ plant $\mathrm{N}+45$ $\mathrm{g} /$ plant $\mathrm{P}+45 \mathrm{~g} /$ plant $\mathrm{K})$. The application of organic manures and inorganic fertilizers $(8$ $\mathrm{kg} /$ plant FYM $+120 \mathrm{~g} /$ plant $\mathrm{N}+45 \mathrm{~g} / \mathrm{plant} \mathrm{P}$ $+45 \mathrm{~g} /$ plant $\mathrm{K}$ ) is recommended for better plant growth, establishment and percentage of survival of Sweet orange (Citrus sinensis 
Osbeck) grafted plants under Allahabad agroclimatic conditions.

\section{References}

Alva AK, Paramasivam S (1998) Nitrogen management for high yield and quality of citrus in sandy soils. Soil Science Society American Journal 62, 13351342.

Bakšienė E., Ražukas A., Repečkienè J., Titova J. 2014. Influence of different farming systems on the stability of low productivity soil in Southeast Lithuania. Zemdirbyste-Agriculture, 101 (2): 115124.

Diacono M. and Montemurro F. 2010. Longterm effects of organic amendments on soil fertility. A review. Agronomyfor Sustainable Development, 30 (2): 401422.

Fageria N. K. 2012. Role of soil organic matter in maintaining sustainability of cropping systems. Communications in Soil Science and Plant Analysis, 43: 2063-2113.

Gupta, S.N., 2012. Instant Horticulture. Jain BrothersPublication, Karol Bagh, New Delhi, India, 10:30.

Malle, J., Raivo V. and Kalvi T.,2017.The importance and profitability of armyard manure application to an organically managed crop rotation. ZemdirbysteAgriculture, vol. 104, No. 4, 321-328.

Muthukumar, P. and Selvakumar, R., 2013.Glaustas Horticulture. New Vishal Publications, Patel Nagar New Delhi, 1: 104-105.

Nilankar, R.G. and Patil, V.K. (1982) Status of Citrus decline in India. Agri. Rev. 19(4) 227-238.

Tanaka, T. (1977). Fundamental discussion of citrus classification. Studiaitrologica., 14(1):6

\section{How to cite this article:}

Jayram Verma, Sevan Das Khunte, Sandeep Lakra and Prasad. V.M. 2020. Roll of Organic Manures and Different Doses of N, P, K on Growth, Establishment and Percentage of Survival of Sweet Orange (Citrus sinensis Osbeck) Grafted Plants. Int.J.Curr.Microbiol.App.Sci. 9(01): 1629-1632. doi: https://doi.org/10.20546/ijcmas.2020.901.179 